\title{
Global Supply Chain Practices and Problems Facing Developing Countries: A Study in Tanzania
}

\author{
Kabossa A.B. Msimangira \\ Department of Higher Education - Business, Faculty of Business, Hospitality and Primary Industries, \\ Melbourne Polytechnic, Australia \\ E-mail: KabossaMsimangira@nmit.edu.au (Corresponding Author)
}

Clemence P. Tesha

Procurement and Supplies Professionals and Technicians Board, Tanzania

E-mail: ctesha@yahoo.com

\begin{abstract}
Although global supply chain is widely discussed by practitioners and academics, and the widespread international recognition of global supply chain practices and problems, little is known in the literature concerning the global supply chain problems facing developing countries. This study aims to identify key problems affecting global sourcing processes in the global supply chain, with reference to the transport sector in Tanzania. We used a case-based research approach by conducting in-depth interviews with senior procurement and supplies managers. Secondary data were collected from the companies' websites and annual reports. Also, direct observation on the companies' operations helped to make the study empirically grounded. We used cross-case analysis to analyse the data. The findings reveal that the local end component of the global supply chain in Tanzania faces many problems compared to that of developed countries; for example, key problems facing Tanzania are: the use of outdated technology in the domestic market, lack of trust, documentation problems, procurement of counterfeit products (e.g., spare parts), and lack of integrated computerised systems to link with the overseas suppliers in the global supply chain, and so on. The insights on problems and practices provide valuable information to researchers and practitioners on the challenges and opportunities in the global supply chain sourcing processes in developing countries. We provide recommendations to solve some of the global supply chain problems.
\end{abstract}

Keywords: global supply chain, public transport, developing countries, Tanzania

\section{INTRODUCTION}

Global supply chain management has tremendously gained importance since the past decades due to the global competitive business environment. Christopher et al. (2006) stress on the need of supply chain design for global operations and they argue that the choice of supply chain strategy impacts competitive performance. The internationalisation or globalisation of supply chains has increased foreign competition in the countries' local markets. For this reason, companies must make quick and wise decisions at strategic and operational levels (Msimangira, 2003) regarding the procurement of goods and services globally in order to minimize the extent of procurement risks or problems. Procurement firms establish relationships networks with their key suppliers when they perceive supply risks (Cheng et al., 2012). Their study on supply risk management via relational approach in the Chinese business context reveals that improved communication and supplier trust are positively related to supplier performance (Cheng et al., 2012), Sun et al. (2012) and emphasised that in order to "mitigate quality risks, supply chain members are coordinated by sharing their information" (p. 58). This result supports Banomyong \& Childerhouse (2010) on integration of the global supply chain.

All decisions on global supply chain must be linked to the company's corporate strategy in order for the company to perform well in the global business competitive environment. Key decision areas in the global supply chain management e.g., determining the source of product/service, location of suppliers, transportation modes, distribution channel, finance, and skilled personnel to manage the supply chain can affect the global purchasing/procurement. It requires effective and efficient management, planning, control, and co-ordination of all activities in the supply chain to purchase sufficient goods from the source (e.g., overseas) to the local final consumer or user in the organisation. Narasimhan \& Das (2001) stress the need for purchasing integration. However, Wood et al. (2002), MacCarthy \& Atthirawong (2003) argue that it is more difficult to manage global supply chains than domestic supply chains. Dornier et al. (1998) revealed that global supply chains carry risks, such as variability and uncertainty in currency exchange rates, economic and political instability, and changes in the regulatory environment that influence performance. The organisation must perform the global supply chain activities when needed at the right time, not earlier or later in the global supply chain. Prasad et al. (2001) \& Prater et al. (2001) emphasise on the quick response to changes in the global environment. But, Colicchia et al. (2010) argue that increased distances between sources of supply and final markets add uncertainty to supply continuity due to longer and variable lead times. Companies must examine critically the value added activities by the global supply chain and their impact on the company's performance. The global sourcing process, if not handled properly, can hinder the performance of the company. A recent study on risks and risks mitigations in 
the supply chain of Mangosteen (fruit) in Indonesia conducted by Astuti et al (2013) identified business relationships between partners and return on investment uncertainty as key risks of the chain to achieve its goal. Although the problems and risks of global supply chains or global sourcing processes are well documented in the literature (e.g., Manuj \& Mentzer, 2008; Barry, 2004) for developed countries, little is known regarding the problems of the global supply chain practices in the transport sector of developing countries.

The objective of this paper is to examine the existing global supply chain problems facing developing countries, with reference to Tanzania. This paper focuses on the public transport sector, which has received little attention in the previous studies in reference to the developing countries, such as Tanzania, and highlights the responses from the procurement and supplies officers and chief supplies managers of the two leading transport companies (labelled $\mathrm{X}$ and $\mathrm{Y}$ ) in Tanzania. It is based on the experiences of the senior supplies managers with global supply chain knowledge and skills. The paper discusses the following: global supply chain network in the public transport sector in Tanzania, literature review, research methodology, results and discussion, conclusions and recommendations, and limitation and future research.

Most countries in developing countries like Tanzania benefit in engaging in global supply chain by purchasing goods and services globally or internationally in order to meet the customer requirements at low costs. However, global supply chain end component in developing countries like Tanzania faces many problems, at a company level, as well as at government level, due to the regulations.

\section{GLOBAL SUPPLY CHAIN NETWORK IN PUBLIC TRANSPORT SECTOR IN TANZANIA}

The problems in the implementation of the global supply chain sourcing process affect the Tanzanian public transport companies' performance. The results of this study lead to a clear understanding of the nature of problems and practices in the end component of the global supply chain in Tanzania. Figure 1 shows the current global supply chain network in the public transport sector in Tanzania. Goods move from various global suppliers to the Tanzanian port of entry (harbour or airport), bonded warehouses, customs department, local transport companies (Tier 1 - Customers), and the final tier 2 customers (passengers/users). There is physical movement of goods and provision of services from the suppliers to customers (passengers/users), and the flow of information and cash (payments) from the customers to the global / international suppliers. Members of the global supply chain must add value in the supply chain process in order to improve the companies' performance.

\section{Supply of goods and services}

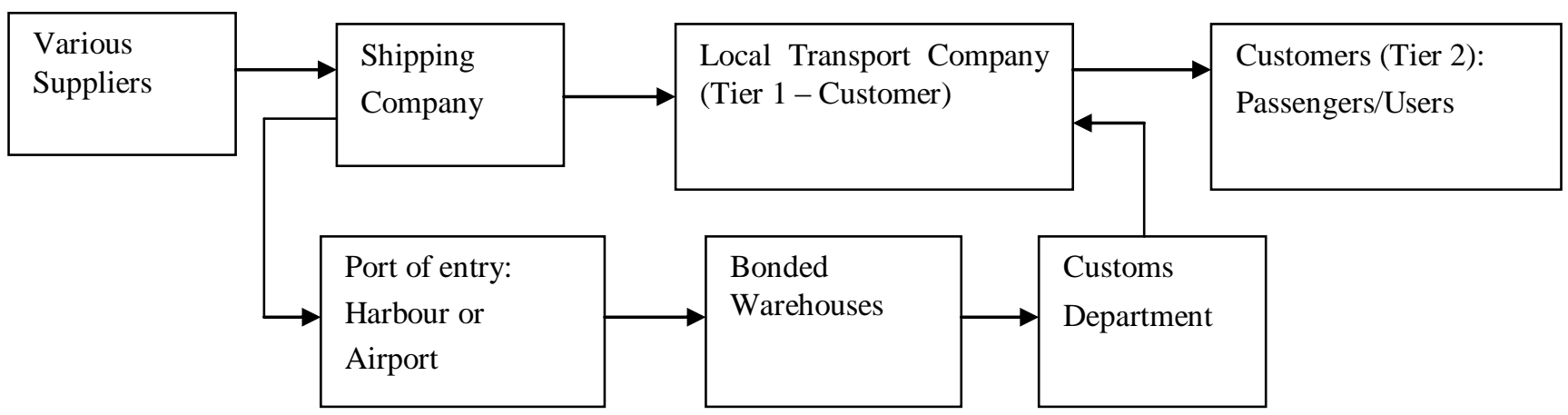

\section{Information and cash flow from the customers}

Figure 1. The Global Supply Chain Network from Global Suppliers to Customers in Tanzanian Public Transport Sector

\section{LITERATURE REVIEW}

\subsection{Supply Chain}

The competition in a global market has forced companies (organisations) to focus on supply chains where the inter-network competition is based. Mentzer, et al. (2001) define supply chain as a set of companies involved in the upstream and downstream flows of products, services, finances, and information from a source to a customer.

Supply chain is a complex network of organisations covering both on the upstream side including tiers of suppliers and on the downstream side including a network of customer companies, retailers, and financial consumers
(Desouza, et al., 2003). Dershin (2000) claims that the supply chain is the "mother of all processes" because of the nature of its size, scope, and complexity, nearly all the processes in the supply chain are not under control. In addition, Msimangira (2003) emphasise that the purchasing and supply chain function is strategic, and supply chain executives need training in supply chain management (SCM) processes. Tracey \& Smith-Doerflein (2001) also stress the need for trainers to assist in the development of individuals in the area of supply chain management. The findings from the study by Gowen III \& Tallon (2003, p. 32) propose that "an interactive role of managerial and employee support to enhance the effectiveness of employee 
support to training and to mitigate the adverse effect of implementation barriers on the success of SCM practices."

In order for an organisation/business to be successful in the competitive environment, there is a need to integrate an organisation's network of a commercial relationships. Competition is no longer among separate businesses, but among groups of firms that are linked together in a chain for delivering customer value (Chandra, 2000).

\subsection{Global Supply Chain}

Global supply chain management (GSCM) has been gaining importance for nearly two decades. The increase in global business competition has forced the companies to reexamine their global supply chain management processes for moving goods and provision of services globally in order to remain competitive. Although GSCM literature is growing, the issue of global / international supply chain problems in developing countries has received little attention (Msimangira \& Tesha, 2009). Much of the discussion has concentrated on global supply chain practices in developed countries, and less emphasis on problems facing suppliers or buyers in the supply network from developing countries. Companies in developed countries put more emphasis on supply chain performance with their competitors.

Global suppliers need to know their customers' demand. According to Bowersox (1997), demand integration requires the companies to develop a set of profound long-term agreements to improve relationships with selected customers and suppliers. The idea of integration is supported by many authors (e.g., Narasimhan \& Das, 2001; Msimangira, 2010; Childerhouse \& Towill, 2011). But, there are few global / international supply chain practices which have been investigated (e.g., Blowfield, 2003; Robertson, 2003; Rienstra, 2004; Wasti et al., 2006; Taps \& Steger-Jensen, 2007; Barnes \& Morris, 2008; Krueger, 2008). A recent study conducted by Gualandris et al. (2014) confirms that supply management and global sourcing have impact on sustainability performance of the company. The literature covers less information on the global / international supply chain in the transport sector.

David (1995, p. 343) defined an international supply chain as "a complex, dynamic system in which disruptions interact with long shipping and lead times to generate costs." Furthermore, David (1995) conducted a study on international sourcing and supply chain stability, and found that demand-related disruptions caused significant and unexpected costs in terms of expedited shipping high inventories, and lower demand fulfilment. Also, Birou \& Fawcett's (1993) research on international purchasing benefits, requirements, and challenges revealed that the key challenges to international sourcing include technical issues like logistics challenges to cope with long supply chains, the search for qualified suppliers, culture and language differences, duty, and customs regulations. Msimangira \& Tesha (2009) found similar challenges in their study on international supply chain practices in Tanzania (a developing country).

Klassen \& Whybark's (1994) study on barriers to management of international operations identified top four barriers: complexity of global logistics, the management of a network of foreign plants, and concerns about culture, and language differences. They stated that the key barriers are composed of managerial concerns and technical issues. Their findings are similar to prior research by Birou \& Fawcett (1993). In addition, Fawcett et al. (2008, p. 35) found that "all managers recognize technology, information, and measurement systems as major barriers to successful supply chain collaboration. The people issues such as culture, trust, aversion to change, and willingness to collaborate are more intractable." Msimangira \& Venkatraman (2014)'s study support the findings of Fawcett et al. (2008). Also, the importance of sharing information in the supply chain has been addressed by many authors, including: Zailani et al. (2008), Otchere et al. (2013), Msimangira \& Venkatraman (2014).

Morash \& Clinton (1997) found that international trade, sourcing, and global transportation pipelines need knowledge of countries' supply chain networks in order to establish seamless and efficient transportation, and logistics performance. Their study results confirm that different countries employ different existing transportation and logistics structural methods to achieve supply chain integration. Furthermore, Morash \& Clinton (1997, p. 5) stated that "structural integration of supply chain such as operational coordination and information sharing, can reduce transportation time and thus total supply chain costs" and they emphasised that Just-in-Time (JIT) delivery is important. However, Msimangira's (1993) study on using JIT in developing countries revealed that there are many problems which affect the usage of JIT, such as international delivery delays, inadequate transportation infrastructure, unreliable product demand forecasts, and financial constraints. Akkermans et al. (1999) propose that it is possible to implement effective international supply chain management strategies by promoting cross-functional careers and by actively responding to customer needs, and the idea is supported by Oliva \& Watson (2011). In addition, Prasad, et al. (2001) argue that supply chains learn and adapt to the dynamic global environment. Prater et al. (2001) support the findings of Prasad, et al. (2001) and conclude that "to be reliable in an certain and changing environment, firms must be able to quickly respond to changes" (Prater et al., 2001, p. 823). Furthermore, Soni \& Kodaly (2011) emphasise on the strategic fit between competitive strategy and supply chain strategy.

Sheu, et al. (2006) warn about international supply chain security, and stress that security issues need to be solved before international supply chain becomes a fully collaborative system. Furthermore, Fawcett et al. (2008) state that people are the key bridge to successful collaborative innovation in supply chain enablers, such as technology, information, and measurement systems. In this regard, Krueger's (2008) research addresses ethical issues surrounding global supply chains of multinational companies in developing countries, with reference to China and points out that "global firms face severe constraints in their full capacity to enhance the dignity and character of workplace conditions in China" (Krueger, 2008, p. 113). In addition, Ras \& Vermeulen (2009) argue that value systems of the developed countries are forwarded towards developing countries.

Overall, the literature findings show that companies participating in the global / international supply chain are 
facing different problems. Many researchers (e.g. Christopher et al., 2011; Blome \& Schoenhen, 2011; Sodhi et al., 2012) have concentrated on supply chain risk management for different sectors but less information on the transport sector. The study conducted by Christopher et al. (2011) on approaches to managing global sourcing risk revealed that many companies do not have a structured supply risk management and mitigation system and rely on informal approaches to cope with risk. They grouped risks into four categories: supply risk, process and control risks, environmental and sustainability risks, and demand risks. The problems of global supply chain facing the developing countries are less investigated compared to that of the developed countries. Little is known regarding the problems affecting global sourcing process in the transport sector in developing countries, with reference to Tanzania and similar developing countries. The research question for this study is: what are the key problems of global supply chain facing Tanzania, and how to solve them?

\section{RESEARCH METHODOLOGY}

The objective of this study is to explore the global supply chain problems and risks facing the developing countries, with reference to the transport sector in Tanzania. Since the study is exploratory, we used a qualitative data collection method, using a case study research approach, which is appropriate to the exploratory and the interpretive research approach (Yin, 2003; Eisenhardt, 1991). We interviewed senior supply chain managers in the field and obtained additional information from secondary data sources (the companies' websites and annual reports). A case study approach helped us to understand social phenomena on the transport sector cases using multiple sources of evidence (Yin, 2003). Yin (2003) states that the case study approach is a good strategy when "how" or "why" questions are being asked; the investigator has little control over events; and the focus is on a contemporary phenomenon (in this case global supply chain practices and problems) within real life context. The case study shows why two large transport public companies (one company covers a distance of 1860 Kilometres and another one covers a distance of 2600 Kilometres (one way trip)), have different experiences regarding the global supply chain operations (see Table 1). The data collection was based on the process proposed by Eisenhardt (1989) and Miles and Huberman (1994). The case is defined by Miles and Huberman (1994) as " $a$ phenomenon of some sort occurring in a bounded context. The case is "in effect, your unit of analysis" (p. 25). Our study was concerned with the perceptions of the supply chain managers' experiences on practices and problems, and how they can solve the existing global supply chain problems. We used the definition and context (Miles \& Huberman, 1994) to set boundaries of a case study.

\subsection{Sample Selection}

We used the purposeful sample for this research (Miles and Huberman, 1994). We invited five senior procurement and supply managers from five leading transport companies in Tanzania to participate in this study. Only two senior procurement and supplies managers from two leading companies accepted to participate in this exploratory study aimed to gain an understanding of current global supply chain practices. The transport companies selected for analysis are the largest transport companies in Tanzania operating effectively and efficiently as part of the global supply chain. The common factor was that both senior managers had engaged in global supply chain processes for many years. Although transport companies under-study have been trying to operate effectively and efficiently, they are struggling to survive in the competitive global supply chain.

\subsection{Data Collection}

We used a triangulation multiple data sources of evidence, as a strategy to enhance data credibility (Yin, 2003). The primary data were collected using in-depth structured interviews. We used a semi- structured interview questionnaire. The development of the interview questionnaire based on the initial interviews with three senior supplies managers from three transportation companies. Three managers engaged in global sourcing process reviewed the questionnaire and pre-tested it. Semistructured interview questionnaires were mailed to two participating senior procurement and supplies managers before the interview, and this shortened the time to respond to the questions during the interview. It was easy for the respondent to follow the questionnaire during the interview. In order to limit biases from a single key respondent, we also interviewed two junior procurement and supplies officers from the same companies which participated in the study to get more insights on the nature of global supply chain practices and problems, and we obtained similar results. Other data sources used in this study were: documentation, direct observations, and participant observation to improve construct validity and reliability of the study using multiple sources of evidence, as suggested by Yin (2003). Multiple respondents (Dubois \& Araujo, 2007) and using many highly knowledgeable informants can limit interview bias (Eisenhardt \& Graebner, 2007; Beverland \& Lindgreen, 2010). In order to conduct a case study in an effective way and enhance the validity and reliability, we followed the case study research process recommended by Kähkönen (2011)..

\subsection{Data Analysis}

We analysed two large transport companies to determine the key issues (Eisenhardt, 1989) and used crosscase analysis technique (Yin, 2003) to analyse the data where the measurements of interest in one company were tested in the other company. The techniques for analysis in this study were: matching, cross-case synthesis, and multiple data sources for two major transport companies concerning their experiences in the global supply chain practices and risks. Data reduction was done using categories of problems and aggregated data helped to understand the overall case, and no data analysis software was used due to the small sample.

\section{RESULTS AND DISCUSSION}

The objective of the study was to study global supply chain practices and problems facing developing countries, with reference to Tanzania. Respondents were asked to provide information based on their experiences with the global supply chain practices and problems. The analysis 
was based on pattern making and comparison of interviews and secondary data sources. The results indicated in Table 1 show the key common global supply chain problems reported by two senior procurement and supplies managers: (1) use of outdated technology in the domestic market, (2) lack of trust, (3) documentation problems, (4) lack of integrated computerised system to link with suppliers, (5) non-existence of original suppliers, (6) procurement of counterfeit products (spare parts), (7) currency for payments and fluctuation of value, (8) cultural differences, (9) specification requirements, (10) difficulty to assess suppliers, (11) procurement function not normally involved in some procurement processes, and (12) unacceptable international commerce terms (incoterms) used by the suppliers. In addition, during the interviews, senior procurement and suppliers managers suggested that the existing problems must be solved first through collaboration between the local buyers and overseas sellers (suppliers), before attaining an effective global supply chain in a competitive global business environment.

This study reveals that though both large transport companies operate in the same domestic business environment, some of the problems are unique to each company (see Table 1), such as problems numbers 5, 7, 8 and 9, due to the nature of business. The problems identified in this study support the findings revealed in the literature (e.g., Birou \& Fawcett, 1993; Klassen \& Whybark, 1994 Fawcett, et al., 2008; Colicchia et al., 2010; Cheng et al., 2012; Astuti et al., 2013). Though the respondents didn't cite training in global supply chain management as a problem during the interview, one respondent stated after the interview that the problem of top management not involving procurement and supplies personnel when buying capital goods is a clear picture of the level of training and lack of recognition of procurement at the strategic level of the organisation. This shows that there is a need to train top management in supply chain management, as suggested by Msimangira (2003). He identified a similar problem in a study on the role of senior and middle management in developing countries, which revealed that middle managers have more practical vision for future than top (senior) managers (Msimangira, 1994).

Table 1. Key Global Supply Chain Problems Facing Tanzanian Transport Sector

\begin{tabular}{|c|c|c|}
\hline Problem & Company X & Company $Y$ \\
\hline 1. The use of outdated technology in the domestic market & $\sqrt{ }$ & $\sqrt{ }$ \\
\hline 2. Lack of trust - sometimes suppliers fail to meet the agreed delivery time & $\sqrt{ }$ & $\sqrt{ }$ \\
\hline $\begin{array}{l}\text { 3. Documentation - failure or delay of the supplier to submit final documents required } \\
\text { for clearing goods at port of entry e.g., Request for Information (RFI) form }\end{array}$ & $\sqrt{ }$ & $\sqrt{ }$ \\
\hline 4. Lack of integrated computerised system to link with suppliers & $\sqrt{ }$ & $\sqrt{ }$ \\
\hline $\begin{array}{l}\text { 5. Some of the original manufacturers of parts no longer exist - importers are forced to } \\
\text { make special orders for spare parts }\end{array}$ & $\cdots$ & $\sqrt{ }$ \\
\hline 6. Procurement of counterfeit products (spare parts) & $\sqrt{ }$ & $\sqrt{ }$ \\
\hline 7. Quality assurance determines the nature of supply chain and it can be expensive & --- & $\sqrt{ }$ \\
\hline 8. Manufacturers/suppliers don't accept small orders & $\sqrt{ }$ & $--\cdot$ \\
\hline 9. Price increases before opening a letter of credit in favour of the supplier & -- & $\sqrt{ }$ \\
\hline 10. Lack of reliable internet services, especially speed & $\sqrt{ }$ & $\sqrt{ }$ \\
\hline 11. Currency requirement for making payments to the suppliers & $\sqrt{ }$ & $\sqrt{ }$ \\
\hline 12. Suppliers sometimes select expensive method of transport & --- & $\sqrt{ }$ \\
\hline 13. Suppliers' culture is imposed on local transport operations & $\sqrt{ }$ & $\sqrt{ }$ \\
\hline 14. Overseas suppliers require expensive specifications and drawings of products & $\sqrt{ }$ & $\sqrt{ }$ \\
\hline $\begin{array}{l}\text { 15. Difficulty to obtain information on the reliability of the overseas supplier (difficulty to } \\
\text { assess overseas suppliers) }\end{array}$ & $\sqrt{ }$ & $\sqrt{ }$ \\
\hline 16. Procurement function sometimes is not involved in making procurement decisions & $\sqrt{ }$ & $\sqrt{ }$ \\
\hline $\begin{array}{l}\text { 17. International commerce terms (Incoterms) used - suppliers offer cost, insurance, } \\
\text { and freight (CIF) delivery terms, but the country's import policy requires the use of cost } \\
\text { and freight (C\&F). }\end{array}$ & $\sqrt{ }$ & $\sqrt{ }$ \\
\hline
\end{tabular}




\section{CONCLUSIONS AND RECOMMENDATIONS}

The purpose of this study was to explore global supply chain practices and problems facing developing countries, with reference to the public transport sector in Tanzania. The global supply chain of goods (e.g., spare parts, vehicle engines, etc.) from overseas suppliers to the local public transport companies (buyers or customers) has not been working effectively and efficiently (in the local part of the global supply chain) to meet the requirements of the customers. If low performance service levels continue at the same pace, the government may decide to privatise the companies or enter into a partnership with the private sector in order to alleviate some of the operational problems.

Although both companies understudy gained some benefits from participation in the global supply chain, our findings indicate that all the respondents from the companies agree on the nature of the critical problems they are experiencing in the domestic part of the global supply chain. These problems must be solved first before the domestic part of the supply chain can be efficient, and meet the customers' demand at the right time, with the right quality of transport service, at minimum cost. Efficient domestic supply chain will increase productivity, and improve service level to the customers. In order for the global supply chain to work efficiently, effectively, and add value, there is a need for management to alleviate some of the procurement/sourcing and supply chain problems identified by the procurement and supplies managers. In addition, the government can improve the operations of transport network in the country. Proactive and vision managers (Msimangira, 1994) who can build relationships are needed to make the global supply chain work efficiently and effectively in the domestic market. Although Tanzania has a structured procedure for importing goods from overseas, the global supply chain faces many problems, which need to be solved, before the global supply chain network can work well in Tanzania, and other similar developing countries. Support from top management of the transport companies and the government, and well trained supply chain management personnel to manage the domestic part of the global supply chain, can enhance the importance of global supply chain management in the public transport sector. The need for trained personnel in supply chain management supports the findings of Tracey \& SmithDoerflein (2001), Msimangira (2003), and Gowen III \& Tallon (2003).

The responses in this study indicate that there are many global supply chain management problems, from the overseas suppliers to the local transport companies in the domestic market. Some of the problems are related to the use of outdated technology in the domestic market, lack of trust, documentation problems, quality assurance, procurement of counterfeit products, quantity demanded, price set up, information systems (lack of integrated computerised system to link with suppliers), lack of reliable international communication, payment methods/currencies, incoterms preferred by suppliers, specification requirements for products, clearing procedures of imports, failure to meet delivery time, and value added tax imposed on imported goods. In some cases, the procurement function is not involved in the global supply chain decisions, especially when buying capital goods.

Our findings contribute to the literature by addressing the global supply chain management problems facing the transport sector in developing countries. The findings are additional to the global supply chain problems addressed by other authors (e.g., Dornier et al., 1998; Manuj \& Mentzer, 2008; Barry, 2004, Colicchia et al., 2010; Cheng et al., 2010; Astuti et al., 2013). Also, the study has managerial implications for the practitioners. The study results can assist practitioners to understand key global supply chain problems facing the transport sector in developing countries. Though the study is based on Tanzanian experience, it reflects similar problems existing in other developing countries, as mentioned in the previous studies. The recommendations will assist the practitioners to solve some of the global supply chain problems using multidisciplinary approach suggested by Christopher et al. (2011).

Personnel involved in global supply chain activities need training in global supply chain management in order to manage effectively and efficiently the supply chain, and at the same time minimize the operational costs. In order to improve the economic growth there is a need to upgrade the transport network. Using an effective and efficient transport system, Tanzania and other developing countries can achieve expected national development which can add value to the end of the global supply chain in the domestic market. It is not possible for customers to receive goods/services at the right time if the transport system is ineffective. The government should continue to engage the private sector in the development of the transport infrastructure in order to increase productivity. There is a need to create a more competitive and attractive business environment in Tanzania.

Regarding commercial relationships with overseas suppliers, transport companies in Tanzania should negotiate in advance the contractual business terms. There is a need for both overseas suppliers and customers (importers) to clearly understand the cultural differences in conducting international / global business in order to improve service level and productivity. Suppliers and customers can both benefit in the global supply chain by establishing a fair longterm commercial relationships.

Companies in developing countries need to integrate their operations, especially the sourcing processes into the global supply chain, and collaboration is the best way to remove or reduce obstacles for effective international / global supply chain. Furthermore, there is a need to improve coordination and trust building between the partners in the supply chain (Astuti et al., 2013).

\section{LIMITATION AND FUTURE RESEARCH}

This paper has provided the results of an initial exploratory study on global supply chain practices in the transport sector and an insight for further research in Tanzania, and other similar developing countries. The major limitation of this paper is that the data which were collected from a small sample (two large public transport companies) have low validity and we cannot generalise our findings. The results must be interpreted with caution. Although this study is grounded in empirical observation, an in-depth 
study of global supply chains in the public and private sectors is required to determine hard evidence of the level of global supply chain practices and performance in the transport sector, using a large sample. A similar study can be replicated in other sectors of the economy where global supply chain plays a major role. Also, further study can be conducted on global sourcing process problems and their impact on effective global supply chain relationships and performance.

A future large scale case - based research (using multi sectors) supported by a survey of a large sample of the public and private transport companies, may provide different valid results, and establish a general understanding of the nature of domestic part of the global supply chain. Further research to determine critical problems of global supply chain (through optimization) facing other sectors / industries (apart from transport) in developing countries is required, using a large sample. Also, there is a need to determine how global suppliers can help developing countries to improve global supply chain risk management practices. Furthermore, a research on the extent of supplier or customer development in the global supply chain will add value in the literature.

\section{ACKNOWLEDGEMENT}

The authors wish to thank the senior procurement and supplies officers and supplies managers for their responses to the interview semi-structured questionnaire and interviews. In addition, we thank the Procurement and Supplies Professionals and Technicians Board (PSPTB) in Tanzania for facilitating this study.

\section{REFERENCES}

Akkermans, H., Bogerd, P., and Vos, B. (1999), Virtuous and Vicious cycles on the road towards international supply chain management. International Journal of Operations \& production Management 19 (5/6), pp. 565 - 581.

Astuti, R., Arkeman, M.M.Y., Poerwanto, R., and Meuwissen, M.P.M. (2013), Risks and risks mitigations in the supply chain of mangosteen: A case study. Operations and Supply Chain Management 6 (1), pp. 11 - 25.

Banomyong, R., and Childerhouse, P. (2010), Integrating the global supply chain. International Journal of Production Economics 128 (1), pp. 1 - 2.

Barry, J. (2004), Supply chain risk in an uncertain global supply chain environment. International Journal of Physical Distribution \& Logistics Management 34 (9), pp. 695 - 697.

Barnes, J., and Morris, M. (2008), Staying alive in the global automotive industry: what can developing economies learn from South Africa about linking into global automotive value chains? The European journal of Development Research 20 (1), p. 31.

Baxter, P., and Jack, S. (2008), Qualitative Case Study Methodology: Study design and implementation for novice researchers. The Qualitative Report 13 (4), pp. 544 - 559.

Beverland, M., and Lindgreen, A. (2010), What makes a good case study? A positivist review of qualitative case research published in Industrial Marketing Management, 1971 - 2006 Industrial Marketing Management 39 (1), pp. 56 - 63.

Birou, L.M., and Fawcett, S.E. (1993), International purchasing benefits, requirements and challenges. International Journal of Purchasing and Materials Management 29 (2), pp. 28 37.
Blome, C., and Schoenhen, T. (2011), Supply chain risk management in financial crisis - A multiple case study approach. International Journal of Production Economics 134 (1), pp. $43-57$.

Blowfield, M. (2003), Ethical supply chains in the cocoa, coffee and tea industries. Greener Management International (43), pp. $15-24$.

Bowersox, D.J. (1997), Integrated supply chain management: a strategic imperative. Presented at the Council of Logistics Management Annual Conference, pp. 5 - 8 October, Chicago, II.

Chandra, V. (2000), Supply chain analysis and management. Management Review 12 (1), pp. $16-26$.

Cheng, T. C.E., Yip, F. K., and Yeung, A.C.L. (2012), Supply risk management via guanxi in the Chinese business context: The buyer's perspective. International Journal of Production Economics 139 (1), pp. 3 - 13.

Childerhouse, P., and Towill, DR. (2011), Arcs of supply chain integration. International Journal of Production Research 49 (24), pp. $7441-7468$.

Christopher, M., Mera, C., Khan, O., and Yurt, O. (2011), Approaches to managing global sourcing risk. Supply Chain Management: An International Journal 16 (2), pp. 67 - 81.

Colicchia, C., Dallari, F., and Melacini, M. (2010), Increasing supply chain resilience in a global sourcing context. Production Planning \& Control: The Management of Operations 21 (7), pp. 680 - 694.

David, L.L. (1995), International sourcing and supply chain stability. Journal of International Business Studies 26 (2), pp. $343-360$.

Dershin, H. (2000), Business process design-completing the DNA. Supply Chain Management Review 4 (2), pp. $74-82$.

Desouza, K., A. Chattaraj, G. Kraft. 2003, Supply chain perspective to knowledge management: research propositions. Journal of Knowledge Management 7 (3), 129 138.

Dornier, P.P., Ernst, R., Fender, M., and Kouvellis, P. (1998), Global Operations and Logistics: Text and Cases, Wiley \& Sons, Inc., New York.

Dubois, A., and Araujo, L. (2007), Case research in purchasing and supply management: Opportunities and challenges. Journal of Purchasing and Supply Management 13 (3), pp. 170 - 181.

Eisenhardt, K.M., and Graebner, M.E. (2007), Theory building from cases: opportunities and challenges. Academy of Management Journal 50 (1), pp. 25 - 32.

Eisenhardt, K. (1989), Building theories from case study research. Academy of Management Review 14 (4), pp. 532 - 550.

Eisenhardt, K. M. (1991), Better stories and better constructs: the case for rigor and comparative logic. Academy of Management Review 16 (3), pp. 620 - 627.

Fawcett, S.E., Magnan, G.M., and McCarter, M.W. (2008), Benefits, barriers, and bridges to effective supply chain management. Supply Chain Management: An International Journal 13 (1), pp. 35 - 48.

Gowen III, C.R., and Tallon, W.J. (2003), Enhancing supply chain practices through human resource management. Journal of Management Development 22 (1), pp. 32 - 44.

Gualandris, J., Golini, R., Kalchschmidt, M. G. M. (2014), Do supply management and global sourcing matter for firm sustainability performance? An International Study. Supply Chain Management: An International Journal 19 (3), pp. 258 $-274$.

Kähkönen, A-K. (2011), Conducting a case study in supply management. Operations and Supply Chain Management 4 (1), pp. $31-41$

Klassen, R.D., and Whybark, D.C. (1994), Barriers to the management of international operations. Journal of Operations management 11 (4), pp. 385 - 396. 
Krueger, D.A. (2008), The ethics of global supply chains in China - convergences of East and West. Journal of Business Ethics 79 (1-2), pp. 113 - 120.

MacCarthy, B.L., and Atthirawong, W. (2003), Factors affecting location decisions in international operations - a delphi study. International Journal of Operations \& Production Management 23 (7), pp. 794 - 818.

Manuj, I., and Mentzer, J.T. (2008), Global supply chain risk management strategies. International Journal of Physical Distribution \& Logistics Management 38 (3), pp. 192 - 223

Mentzer, J.T., DeWitt, W.J., Keebler, S., Min, S., Nix, N.W., Smith, C.D., and Zacharia, Z.G. (2001), Defining supply chain management. Journal of Business logistics 22 (2), pp. $1-25$.

Miles, M.B., and Huberman, M. (1994), Qualitative data analysis, Sage Publications, Thousand Oaks, CA.

Morash, E., and Clinton, S.R. (1997), The role of transportation capabilities in international supply chain management. Transportation Journal 36 (3), pp. 5 - 17.

Msimangira, K.A.B., and Venkatraman, S. (2014), Supply chain management integration: Critical problems and solutions. Operations and Supply Chain Management 7 (1), pp. 23 - 31.

Msimangira, K.A.B. (1993), Using "Just-In-Time" in developing countries: A case study in Tanzania. International Journal of Purchasing and materials Management 29 (2), pp. 44 - 52.

Msimangira, K.A.B. (1994), The role of senior and middle management in developing countries: A case study of public manufacturing firms in Tanzania. The International Journal of Public Sector Management 7 (1), pp. 25 - 38.

Msimangira, K.A.B. (2003), Purchasing and supply chain management practices in Botswana. Supply Chain Management: An International Journal 8 (1), pp. 7 - 11.

Msimangira, K.A.B., and Tesha, C.P. (2009), International supply chain practices in developing countries: A study in Tanzania. Production and Operations Management Society (POMS), 20th Annual Conference, Orlando, Florida, U.S.A.

Narasimham, R., and Das, A. (2001), The impact of purchasing integration and practices on manufacturing performance. Journal of Operations Management 19 (5), pp. 593 - 609.

Oliva, R. and Watson, N. (2011), Cross functional alignment in supply chain planning: A case study of sales \& operations planning. Journal of Operations Management 29 (5), pp. $434-448$.

Otchere, A. F., Annan, J., and Anin, E. K. (2013), Achieving competitive advantage through supply chain integration in the cocoa industry: A case study of Olam Ghana Limited and Produce Buying Company Limited. International Journal of Business and Social Research 3 (2), pp. 131 - 145.

Prasad, S., Tata, J., and Motwani, J. (2001), International supply chain management: Learning and evolving networks. Global Journal of Flexible Systems Management 2 (2), pp. 31-36

Prater, E., Biehl, M., and. Smith, M.A. (2001), International supply chain agility - tradeoffs between flexibility and uncertainty. International Journal of Operations \& Production Management 21 (5/6), pp. 823 - 839.

Ras, P. J., and Vermeulen, W. J. V. (2009), Sustainable production and the performance of South African entrepreneurs in a global supply chain. The case of South African table grape producers. Sustainability Development 17 (5), pp. 323 .- 340.

Rienstra, D. (2004), African leather: industry meets world markets International Trade Forum: ITC presents: portraits of trade development (4), pp. 43 - 47.

Robertson, P.L. (2003), The role of training and skilled labour in the success of SMEs in developing economies. Education \& Training 45 (8/9), pp. 461 - 473.

Sheu, C., Lee, L., and Niehoff, B. (2006), A voluntary logistics security program and international supply chain partnership. Supply Chain Management: An International journal 11 (4), pp. $363-374$.

Sodhi, M. S., Son, B - G., and Tang, C. S. (2012), Researchers' perspectives on supply chain risk management. Production and Operations Management 21 (1), pp. 1 - 13.

Soni, G., and Kodaly, R. (2011). The strategic fit between "competitive strategy" and "supply chain strategy" in the Indian manufacturing industry: an empirical approach. Measuring Business Performance. 15 (2), pp. 70 - 80.

Sun, J., Matsui, M., and Yin, Y. (2012), Supplier risk management: An economic model of P-Chart considered due date and quality risks. International Journal of Production Economics 139 (1), pp. 54 - 64.

Taps, S.B., Steger-Jensen, K. (2007), Aligning supply chain design with manufacturing strategies in developing regions. Production Planning \& Control 18 (6), pp. 475 - 486.

Tracey, M., and Smith-Doerflein, K.A. (2001), Supply chain management: what training professionals need to know. Industrial and Commercial Training 33 (3), pp. 99 -104.

Wasti, S.N., Kozan, M.K., and Kuman, A.. 2006, Buyer-supplier relationships in the Turkish automotive industry. International Journal of Operations \& Production Management 26 (9), pp. 947-970.

Wood, D. F., Barone, A.P., Murphy, P.R., and Wardlow, D.L. (2002), International Logistics, AMACOM, New York.

Yin, R. (2003), Case study research: design and methods, Sage Publications, Thousand Oaks, CA.

Zailani, S., Premkumar, R., and Fernando, Y. (2008), Factors influencing the effectiveness of operational information sharing within supply chain channels in Malaysia. Operations and Supply Chain Management 1 (2), pp. 85 100.

Kabossa A.B. Msimangirais is a Senior Lecturer and Discipline Leader of Business in the Department of Higher Education - Business, Faculty of Business, Hospitality and Primary Industries at the Melbourne Polytechnic, Australia. He received his B.A (Honours) (Production and Marketing Management) from the University of Dar es Salaam, Tanzania, an MBA (Operations Management) from the University of Arizona, U.S.A and a PhD (Supply Chain Management) from the Auckland University of Technology, New Zealand. He is a certified Fellow member of the Chartered Institute of Purchasing and Supply (FCIPS), U.K./Australia, and a certified Fellow member of the Chartered Institute of Marketing (FCIM), U.K. He has 34 years of experience in training, consultancy and research in the areas of purchasing / procurement, logistics, management, marketing, operations management, supply chain management, and supply chain integration. Kabossa has published research papers in peer reviewed international journals, including Operations and Supply Chain Management: An International Journal, Supply Chain Management: An International Journal, International Journal of Purchasing and Materials Management, the International Journal of Public Sector Management, and the international Journal of Sustainability Policy and Practice. Before joining NMIT, he worked at various universities, polytechnics and the United Nations. 
Clemence P. Tesha is Executive Director of Procurement and Supplies Professionals and Technicians Board (PSPTB) in Tanzania. He is a PhD candidate in operations and supply chain management, Mzumbe University, Tanzania. He obtained a Masters degree in procurement and logistics management from Mzumbe University. 